\title{
Gross Anatomical Studies on the Celiac Artery in The Domestic Fowl (Gallus gallus domesticus)
}

\author{
H. M. Rezk and S. H. El-Bably
}

Department of Anatomy and Embryology, Fac. Vet. Med. Cairo Univ., EGYPT

\section{Abstract}

The present study was carried out on eight adult, apparently healthy chickens of both sexes. The birds were slaughtered and the descending aorta was cannulated and flushed with warm normal saline $(0.9 \%)$. Then birds were injected with colored gum milk latex. The origin, course and distribution of the celiac artery were studied. The celiac artery originated from the descending aorta in the level with the $5^{\text {th }}$ rib. It proceeded ventrally and slight cranial were it gave off the esophageal artery after few $\mathrm{mm}$ from its origin, the dorsal proventricular artery just before its bifurcation into right and left branches at the cranial end of the spleen.

Key words: Chicken; Arterial supply; GIT; Celiac artery.

\section{Introduction}

Poultry is one of the major sources for meat and egg production, and still the cheapest source of animal people all over the world.

The importance of the poultry among our native livestock have initiated an increasing interest to establish more accurate and specific anatomical facts about the arterial blood supply of the Gastrointestinal

The available literature on the celiac artery and its distribution doesn't provide complete detailed inforSo, the present study aimed to declare this confusion about the course and distribution of the celiac artery in the domestic fowl.

\section{Material and Methods}

The current study was conducted on eight adult, apparently healthy chickens of both sexes, weighing $1.5-2 \mathrm{~kg}$ and aging 5-8 months, it obtained from the chicken farms around Cairo. The birds were slaughtered and the descending aorta was cannulated and flushed with normal saline. The birds were tract of the poultry. mation about the scope of the work. 
injected with $60 \%$ gum milk latex colored red with Rotring ${ }^{\circledR}$ ink. (Tompsett and Wakelly, 1965).

The animals were left in a mixture of $10 \%$ formalin, $2 \%$ phenol and $1 \%$ glycerin for seven days before the routine dissection. The obtained results were photographed using Sony ${ }^{\circledR}$ digital camera $12.1 \mathrm{mp}, 4 \mathrm{x}$.

The nomenclature used was that recommended by the Nomina Anatomica Avium (Baumel et. al., 1993).

\section{Results}

\section{A. Celica}

The celiac artery (Fig.1, 3-5/2) is the first branch of the descending aorta. It leaves the right lateral aspect of the descending aorta at the $5^{\text {th }}$ rib. It passed ventrally from the aorta and gave off the esophageal artery, dorsal proventricular artery then it divided at the level with the cranial end of the spleen into left and right branches of the celiac. It supplied the esophagus, proventriculus, ventriculus, spleen, liver, duodenum, pancreas and parts of the ileum and the left cecum.

\section{A. Esophagealis}

The esophageal artery (Fig. 1, 3 and $5 / 3$ ) was derived from the celiac artery after $5-8 \mathrm{~mm}$ from its origin, it courses cranially about $1 \mathrm{~cm}$ where it enters the dorsal aspect of the esophagus at its junction with the proventriculus. This branch supplied the terminal part of the esophagus and anastomosis cranially with the esophageal branch of the esophageotracheobronchial artery. The esophageal artery of the celiac is not constant branch; in one specimen this branch was detached directly from the descending aorta.

\section{A. Proventriculus dorsalis}

The dorsal proventricular artery (Fig. 1, 3-5/4) was arisen from the left aspect of celiac artery $1.5-2 \mathrm{~cm}$ caudal to the emergence of the esophageal artery. It passed ventrally piercing the right wall of the proventriculus with two branches near its middle third. It gave off 1-2 esophageal branches (Fig. 4 and 5/ $4_{b}$ ) that proceeded cranially to the esophagus, and then continued as the dorsal gastric artery.

\section{A. gastrica dorsalis}

The dorsal gastric artery (Fig. 4 and $5 / 4 a$ ) was the direct continuation of the dorsal proventricular artery; it crosses the right side of the proventriculus and ismuth oblique caudoventrally supplying the isthmus and dorso-lateral muscle of the ventriculus. Its terminal branches anastomosed with that of the left and right gastric arteries.

\section{Ramus sinster arteriae celicae}

The left branch of celiac artery (Fig. 2,3 and $5 / 5$ ) is one of the two di- 
vergences of the celiac artery just after the detachment of the dorsal proventricular artery at the right face of the proventriculus, and then passed to the left side between the proventriculus and left lobe of the liver. It provided the ventral proventricular artery, ventral gastric artery and continued as the left gastric artery. During its course it detached 34 small branches to the ismuth and the cranio-dorsal sac of the ventriculus.

\section{A. Proventrcularis ventralis}

The ventral proventricular artery (Fig. 2 and 5/7) detached firstly from the left branch of the celiac artery at the distal third of the proventriculus, it takes a short dorsal course to penetrate the wall of the proventriculus with 1-2 branches.

\section{A. gastrica ventralis}

The ventral gastric artery (Fig. 2 and $5 / 8$ ) detached from the left branch of the celiac artery at the level with the ismuth. It detached a branch to the left lobe of the liver named the left hepatic artery, pyloric branch between the gizzard and the first part of the duodenum, and then continued on the ventral border of the ventriculus and anastomosed with the branches of the right and left gastric arteries.

\section{A. hepatica sinistra}

The left hepatic artery (Fig. 2 and $5 / 9$ ) detached from the ventral gastric artery. It supplied the left lobe of the liver with 2-3 branches.

\section{A. gastrica sinistra}

The left gastric artery (Fig. 2 and $5 / 10$ ) was the direct continuation of the left branch of the celiac artery after the detachment of the later branches. It passed in the groove between the craniodorsal sac and ventriculus. The left gastric artery terminated by two branches; dorsal branch supplied the dorsal lateral muscle and the ventral branch to the ventral lateral muscle and the caudo-ventral muscle.

\section{Ramus dexter arteriae celicae}

The right branch of the celiac artery (Fig. 1, 3-5/6) considered the $2^{\text {nd }}$ terminate of the celiac artery, it detached from the right aspect of the celiac between the spleen and the right lobe of the liver. It gave off the splenic, right hepatic, gastroduodenal, right gastric and then continued as pancreaticoduodenal artery.

\section{Aa. Splenica (Aa. Lienales)}

The splenic arteries (Fig. 3-5/11) were arisen from the right branch of the celiac about $4 \mathrm{~mm}$ from its bifurcation. The cranial branch passed to the cranial pole of the spleen, while the caudal branches were 2 or 3 
branches, distributed to the caudal pole of the spleen.

\section{A. hepatica dexter}

The right hepatic artery (Fig. 3 and $5 / 12$ ) was originated from the right branch of the celiac artery at the level of the caudal pole of the spleen; it supplied the right lobe of the liver and gall bladder and the duodenojejunal flexure by the duodenojejunal artery.

\section{A. duodenojejunalis}

The duodenojejunal artery detached from the right hepatic, crossing to the left side to supply the duodenojejunal flexure.

\section{A. pancreaticodudenalis}

The pancreaticoduodenal artery (Fig. 3-5/15) was the direct continuation of the right branch of the celiac after the right gastric. It passed along the mesodudenum between the descending and ascending limbs of the duodenum where it supplied a series of branches to the pancreas and duodenal loop. It detached the ileocecal arteries.

\section{A. ileocecalis}

The ileocecal arteries (Fig. 3-5/16) were 3-4 branches, detached at intervals from the first third of the pancreaticoduodenal artery. These branches entered the short ileocecal ligament and distributed to the last third of the ileum and the left cecum.

\section{A. gastrica dexter}

The right gastric artery (Fig. 3-5/14) was arisen from the right branch of the celiac at the proximal end of the descending limb of the duodenum. It divided into dorsal and ventral branches. The dorsal branch gave off branches to the right craniodorsal sac and the right tendenous part. While, the ventral branch gave off branches to the right caudoventral sac and the right tendenous part.

\section{A. gastroduodenalis}

The gastroduodenal artery (Fig. 3$5 / 13$ ) detached from the right branch of the celiac artery left to the origin of the right gastric. It passed to the pyloric region.

\section{Discussion}

The present study revealed that, the celiac artery is the first branch of the descending aorta, supplied the proventriculus, ventriculus, liver, spleen, pancreas, duodenum and parts of ileum and the left ceca. This was in agreement with (Kuru, 2010 in domestic fowls; Aslan and Takci, 1998 in geese; Fowler, 1991 in ratites; King and Mc Lelland, 1984 in domestic fowls; Kurtul and Haziroglu, 2002 in rooster; Lauper et al., 
1975 in pigeon; Silva et al., 1997 in domestic fowls).

In agreement with Getty (1975) in domestic fowls, the celiac artery was detached from the right lateral wall of the descending aorta at the level with the $5^{\text {th }}$ rib. While, Haligur and Duzler (2010) in red falcon reported that, the celiac artery was detached at the level of the 2-3 ribs. On the other hand, (Kuru, 2010 in domestic fowls; Dursun, 2002 in domestic fowls; Franz and Salomon, 1993 in domestic fowls; Miladinovic et al., 1986 in domestic fowls; Lauper et al., 1975 in pigeon; King and Mc Lelland, 1984 in domestic fowls; Kurtul and Haziroglu, 2002 in rooster) stated its origin at the level of the $5^{\text {th }}-6^{\text {th }}$ thoracic vertebra.

Similar to (Kuru, 2010 in domestic fowls; Aycan and Duzler, 2000 in eagle owl; Mc Leod et al., 1964 in domestic fowls; Malinovsky, 1965 in buzzard; Nickel et al., 1977 in domestic fowls) the first branch from the celiac artery was the esophageal artery. However, in one specimen out of eight, the first branch of the celiac artery was the dorsal proventricular artery, similar results reported by Kurtul and Haziroglu, 2002; Silva et al., 1997 in rooster, drake, pigeons and geese and Haligur and Duzler (2010) in two specimens of the red falcons.
In accordance with Kuru, 2010 and Getty, 1975 in domestic fowls the celiac artery was described to bifurcate into left and right branches detaching the dorsal proventricular artery and cranial to the spleen. Haligur and Duzler, 2010 in the red falcon; Kurtul, 2002; Kurtul and Haziroglu, 2002 in rooster; Malinovsky and Novotna, 1977 in domestic fowls; Pinto et al., 1998 in ducks determined the celiac artery to split between the proventriculus and gaster. In contrast, Aycan and Duzler (2000) in eagle owl; Chiasson (1984) in pigeon have reported that the celiac artery does not bifurcate.

The present study declared that, the dorsal proventricular artery was detached from the celiac artery after $1.5-2 \mathrm{~cm}$ from the origin of the esophageal artery. On the contrary, Kuru, 2010 stated this distance as $4 \mathrm{~mm}$ in domestic fowls. While, Haligur and Duzler, 2010 in the red falcon mentioned that this branch was originated in common with the esophageal artery. Nishida et al. (1969) named this vessel as the right glandular gastric artery in domestic fowls.

In this study, similar to the reports of Kuru, (2010) in domestic fowls; Haligur and Duzler, (2010) in red falcon; Aslan and Takci (1998) in gesse; Aycan and Duzler (2000) in 
eagle owl, the dorsal gastric artery lies on the dorsal side of ventriculus and considered as the direct continuation of the dorsal proventricular artery. In contrast, Silva et al., 1997 in domestic fowls stated that, the dorsal gastric artery as a continuity of the pancreaticoduodenal artery in birds.

The left branch of the celiac artery provided the ventral proventricular artery, ventral gastric artery and continued as the left gastric artery, this was in agreement with Kuru, (2010) in domestic fowls; Haligur and Duzler, (2010) in red falcon; Getty, 1975 in domestic fowls. Moreover, Haligur and Duzler, (2010) in red falcon reported that, the left branch of the celiac artery started at the right and gave off the right hepatic artery before coursing to the left.

In accordance with Dursun, (2002) in domestic fowls; Kurtul, (2002) in rooster; Malinovsky and Visnanska, (1975) in goose and Kuru, (2010) in domestic fowls the left hepatic artery was reported to be a branch of the ventral gastric artery in the domestic fowls. In contrast, (Baumel et al., 1993), ducks (Nickel et al., 1977), chickens (Malinovsky and Novotna, 1977) and red falcons (Haligur and Duzler, 2010) stated that, the left hepatic artery arises from the left branch of the celiac artery. In a Eurasian eagle owl (Aycan and Duzler, 2000) the left hepatic artery has been reported to stem from the celiac artery.

The origin of the ventral proventricular artery and the ventral gastric artery were in agreement with Malinovsky and Visnanska, (1975) in goose, Baumel et al., (1993) in domestic fowls, Aslan and Takci, (1998) in gesse, kurtul, (2000), Dursun, (2002) in rooster and Kuru, (2010) in domestic fowls.

The right branch of the celiac artery gives off the splenic arteries, right hepatic artery, right gastric artery, gastroduodenal artery, ileocecal arteries, ileal arteries and pancreaticoduodenal artery (Aslan and Takci, 1998) in geese; (Baumel, 1975) in fowls; (Franz and Salomon, 1993) in domestic fowls; (Silva et al., 1997) in domestic fowls; Kuru, 2010 in domestic fowls. According to the results of the present study the branches of the right branch of the celiac artery are the same except that, the ileal arteries were not found.

In the present study, the splenic artery is a stem from the right branch of the celiac artery agreed the results repoted by Aslan and Takci (1998) in geese; Baumel et al., (1993) in fowls; Doguer and 
Erencin, (1964); Dursun, (2002); Kuru,(2010) in domestic birds; Malinovsky et al., (1973) in duck, On the other hand, the splenic artery originated directly from the celiac artery (Aycan and Duzler, 2000 in eagle owl; Baumel et al., 1993 in domestic fowls; Chiasson, 1984 in pigeon; Haligur and Duzler, 2010 in red falcon). Furthermore, in a study carried out on three different chicken breeds (Malinovsky and Visnanska, 1975 in gosse) the spleen is determined to be vascularised by one or more branches arising from the right hepatic artery in $6-15 \%$, left branch of the celiac artery in $15 \%$, and superior proventricular artery in 27 $57 \%$ of the birds examined. In one of the red falcons (Haligur and Duzler, 2010 in red falcon) two short branches originating from the celiac artery and the right branch of the celiac artery are determined to extend to the spleen and in seven falcons, the splenic arteries are determined to have their origin at the celiac artery. In the domestic fowls examined in the present study, the first branches of the right branch of the celiac artery were splenic arteries; this finding is also in compliance with previous researches (Doguer and Erencin, 1964 in domestic fowls; Dursun, 2002 in domestic fowls; Malinovsky, 1965 in buzzard ; Malinovsky et al., 1973 in duck; Malinovsky and Visnanska, 1975 in goose; Malinovsky and Novotna, 1977 in domestic fowls; Nickel et al., 1981 in domestic fowls; Kurtul, 2002 in rosster, Kuru, 2010 in domestic fowls).

In agreement with the findings of (Aslan and Takci, 1998 in geese, Baumel et al., 1993 in domestic fowls; Dursun, 2002 in domestic fowls; Mc Leod et al., 1964 in domestic fowls; Malinovsky, 1965 in buzzard; Malinovsky et al., 1973 in duck; Malinovsky and Visnanska, 1975 in goose; Malinovsky and Novotna, 1977 in domestic fowls; Nickel et al., 1981 in domestic fowls; Kurtul, 2002 in rooster, Kuru, 2010 in domestic fowls) the right hepatic artery was detached from the right branch of the celiac artery. In contrast to this Haligur and Duzler, (2010) in red falcon described the right hepatic artery originating from the left branch of the celiac artery.

In the present investigation, the ileocecal artery arose from the pancreaticodudinal artery as described by Kuru, (2010) in domestic fowls and Haligur and Duzler, (2010) in the red falcon. On the other hand, the ileocecal artery arose from the cranial mesenteric artery and supplies the corresponding regions in the pigeon (Kurtul and Haziroglu, 2002 in rooster). The ileocecal artery supplies the ileum in the pigeon 
(Silva et al., 1997 in domestic fowls; Kurtul and Haziroglu, 2002 in rooster) and Haligur and Duzler, (2010) in the red falcon. The ileocecal artery of this study supplied the left cecum and the terminal part of the ileum as reported by Kuru (2010) in the domestic fowl.

\section{References}

Aslan, K. and Takci, I. (1998): The arterial vascularisation of the organs (stomach, intestinum, spleen, kidneys, testes and ovarium) in the abdominal region of the geese obtained from Kars surrounding (in Turkish). Kafkas University, Fac. Vet. Med. J., 4: 49-53.

Aycan, K. and Duzler, A. (2000): The anatomy of celiac artery in the eagle owl (Bubo bubo) (in Turkish). Ankara University, Fac. Vet. Med. J., 47: 319-323.

Baumel, J. J. (1975): Aves Heart and Blood Vessels. In, Sisson and Grossman's the Anatomy of the Domestic Animals. Getty R (Eds.), Vol II, 5 th ed. Saunders Company, Philadelphia, 1990-1991.

Baumel, J. J., King, S. A., Breasile, J. E., Evans, H. E. and Berge, J. C. V. (1993): Nomina Anatomica Avium. Published by the
Nuttall Ornithological Club. No: 23, Cambridge, Massachusets.

Chiasson, B. R. (1984): Laboratory of the Pigeon. $3^{\text {rd }}$ edition. Brown Company Publishers, Dubuque, Iowa, pp. 34-41.

Doguer, S., Erencin, Z. (1964): Com-parative Anatomy of Domestic Birds. The Veterinary Medicine Faculty Publishers, Ankara University Press, Ankara, pp. 72-73.

Dursun, N. (2002): Anatomy of Domestic Birds (in Turkish). Medisan Publishing, Ankara, pp. 140-141.

Fowler, M. E. (1991): Comparative clinical anatomy of ratites. J. Zool. Wild. Med., 22: 204-227.

Franz, V. and Salomon, V. (1993): Lehrbuch der Geflügel anatomie. Gustav Fischer Verlag,Jena, Suttgart.

Getty R. (1975): The Anatomy of the Domestic Animals. 5th ed. WB Saunders Company, NewYork.1990-1991.

Haligur, A. and Duzler, A. (2010): Course and branch of the celiac artery in the red falcon (Buteo rufinus). Vet. Med., 55(2): 79-86. 
King, A. S. and Mc Lelland, J. (1984): Birds, Their Structure and Function. $2^{\text {nd }} e d$, Bailliere Tindall, England.

Kurtul, I. (2002): Comparative macro-anatomical investigations on the pattern and branches of the aorta descendens among the rooster, drake, and pigeon (in Turkish). [PhD thesis.] Fac. Vet. Med. Ankara Univ., pp. 24-37.

Kurtul, I. and Haziroglu, R. M. (2002): Comparative macroanatomical investigations on the pattern and branches of the descending aorta among the rooster, drake, and pigeon (in Turkish). J. Fac. Vet. Med., Ankara Univ., 51: 1-6.

Kuru, N. (2010): Macroanatomic investigations on the course and distribution of the celiac artery in domestic fowl (Gallus gallus domesticus). Scientific Research and Eassays Vol.5 (23), pp. 3585-3591.

Lauper, N. T., Unni, K. K., Kottke, B. A. and Titus, K. L. (1975): Anatomy and histology of aorta of White Carneau pigeon. Lab. Invest., 32: 536-551.

Malinovsky, L. (1965): Blood supply to stomachs and adjacent organs in Buzzard. Folia Morphologica (Praque) , 13: 191-201.
Malinovsky, L. and Novotna, M. (1977): Branching of the coeliac artery in some domestic birds. III. A. Comparison of the pattern of the coeliac artery in three breeds of the domestic fowl (Gallus gallus f. domestica). Anat. Anz, 141: 136-146.

Malinovsky, L. and Visnanska, M. (1975): Branching of the celiac artery in some domestic birds, II. The domestic goose. Folia Morphologica (Prague). 23: 128-135.

Malinovsky, L., Visnanska, M. and Roubal, P. (1973): Branching of a. celiaca in some domestic birds. I. Domestic Duck (in Czech). Scripta Medica, 46: 325-336.

Miladinovic, Z., Popoic, S. and Jojic, D. (1986): Vascularization of the glandular stomach of the hen (Gallus domesticus). Acta Vet., 5(6): 335-342.

McLeod, W. M., Trotter, D. M. and Lumb, J. M. (1964): Avian Anatomy. Burgeaa Publishing Company, 82: 133-134.

Nickel, R., Schummer, A. and Seiferle, E. (1977): Anatomy of the Domestic Birds. Verlag Paul Parey, Berlin.

Nickel, R., Schummer, A. and Seiferle, E. (1981): The Anatomy of 
the Domestic Animals. Vol 3, Verlag Paul Parey, Berlin, 95.

Nishida, T., Paik, Y. K. and Yasuda, M. (1969): Blood vascular supply of the glandular stomach (Ventriculus glandularis) and the muscular stomach (Ventriculus muscularis). Jpn. J. Vet. Sci., 31: 51-70.

Pinto, M. R. A., Riberio, A. A.CM. and Souza, W. M. (1998): Os arranjos configurados pela arteria celiaca no pato domestico (Carina moshata). Braz. J. Vet. Res. Anim. Sci., 35: 103-106.
Silva e Carneiro, F. O., Severino, R. S., Santos ALQ, Drummond, S. S., Bombonato, P. P., Santana, MIS., Lopes, D. and Marçal, A. V. (1997): Origin and distribution of the artery celiacae in birds (Gallus gallus domesticus-Ross linage). Revista da FZVA,4 (1): 64-76.

Tomsett, D. H. and C. W. Wakeley (1965): Anatomical Techniques. 1st Edition. E \& Living Stone Ltd. Edinburgh and London. 


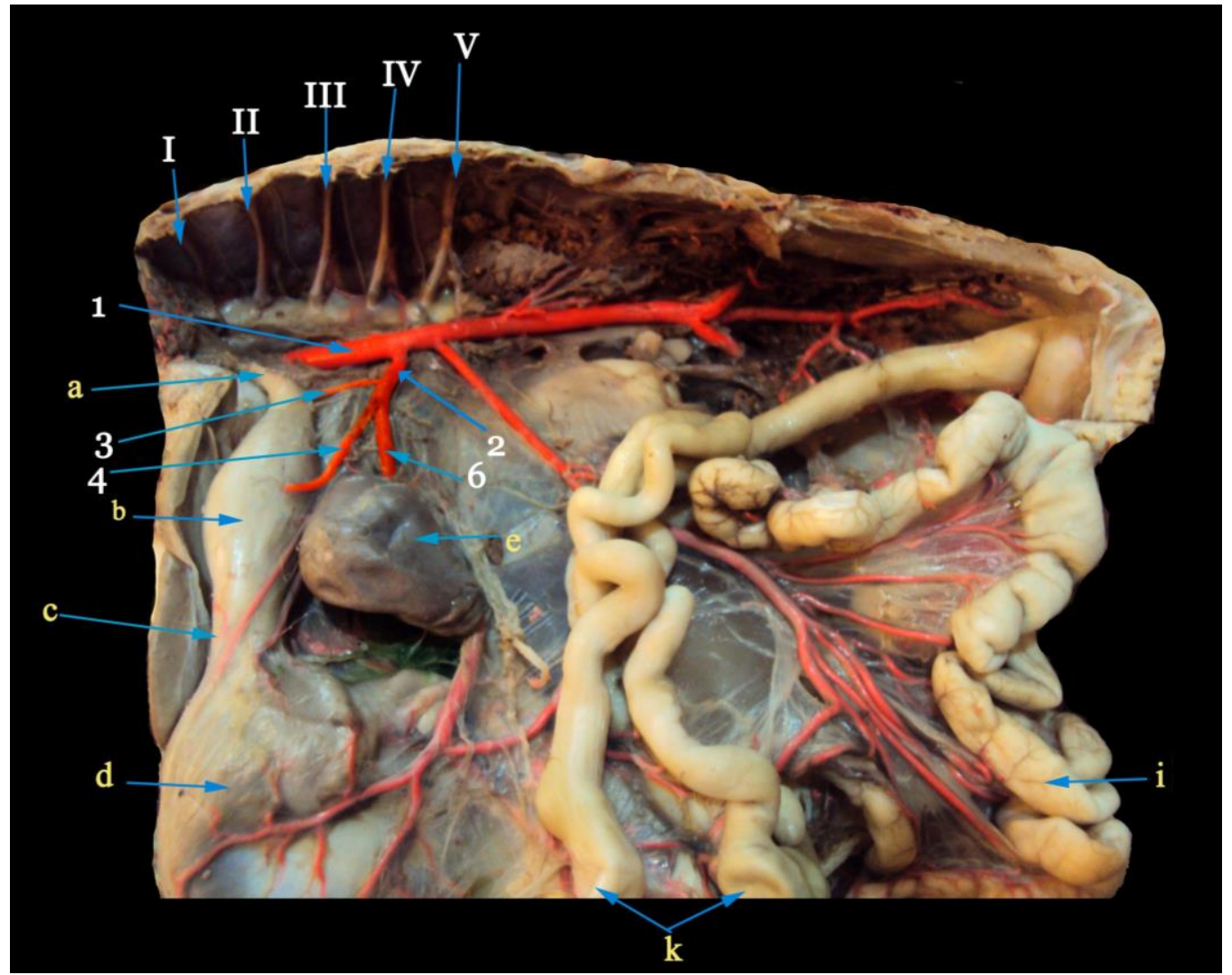

Fig (1): A photograph showing the origin of the celiac artery in chicken

\section{Legend for figures (1-5)}

I-V: Costae (numerical),

a Oesophagus, b Proventriculus gastris, c Ismuth gastris, d Ventriculus gastris, e Splen, $f_{1}$ Lobus sinister hepatis, $f_{2}$ Lobus dexter hepatis, g Duodenum, $h$ Pancreas, i Jejunum, j lleum, k Cecum,

1 Aorta descendens, 2 A. Celica, 3 A. esophagealis, 4 A. proventriculus dorsalis, 4a A. gastrica dorsalis, 4b Rr. Esophageales, 5 Ramus sinster arteriae celicae, 6 Ramus dexter arteriae celicae, 7 A. proventrcularis ventralis, 8 A. gastrica ventralis, $9 \mathrm{~A}$. hepatica sinistra, $9 \mathrm{~A}$. hepatica sinistra, $10 \mathrm{~A}$. gastrica sinistra, 10a A. gastrica sinistra dorsalis, 10b A. gastrica sinistra ventralis, $11 \mathrm{Aa}$. Lienales, $12 \mathrm{~A}$. hepatica dexter, $13 \mathrm{~A}$. gastrodudenalis, $14 \mathrm{~A}$. gastrica dexter, 14a A. gastrica dextra dorsalis,

14b A. gastrica dextra ventralis, 15 A. pancreaticodudenalis, 16 A. ileocecalis.

J. Vet. Anat. 


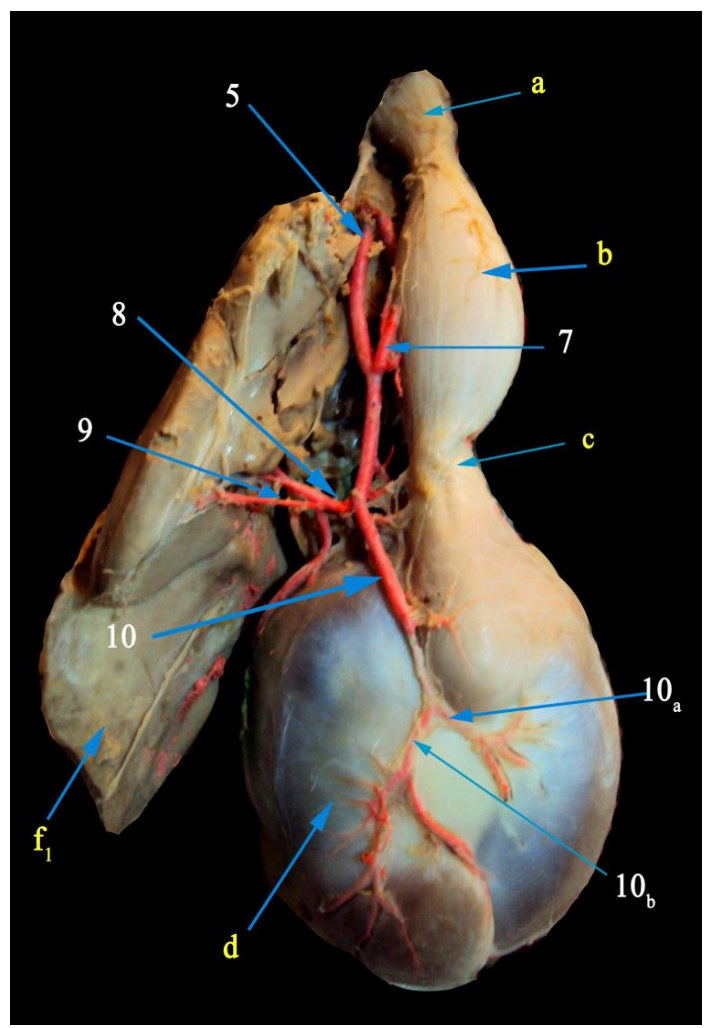

Fig (2): A photograph showing the branches of the left ramus of the celiac artery in chicken.

\section{Legend for figures (1-5)}

I-V: Costae (numerical),

a Oesophagus, b Proventriculus gastris, c Ismuth gastris, d Ventriculus gastris, e Splen, $f_{1}$ Lobus sinister hepatis, $f_{2}$ Lobus dexter hepatis, $g$ Duodenum, $h$ Pancreas, i Jejunum, j lleum, k Cecum,

1 Aorta descendens, 2 A. Celica, 3 A. esophagealis, 4 A. proventriculus dorsalis, 4a A. gastrica dorsalis, 4b Rr. Esophageales, 5 Ramus sinster arteriae celicae, 6 Ramus dexter arteriae celicae, 7 A. proventrcularis ventralis, 8 A. gastrica ventralis, $9 \mathrm{~A}$. hepatica sinistra, $9 \mathrm{~A}$. hepatica sinistra, $10 \mathrm{~A}$. gastrica sinistra, 10a A. gastrica sinistra dorsalis, 10b A. gastrica sinistra ventralis, $11 \mathrm{Aa}$. Lienales, $12 \mathrm{~A}$. hepatica dexter, $13 \mathrm{~A}$. gastrodudenalis, $14 \mathrm{~A}$. gastrica dexter, 14a A. gastrica dextra dorsalis,

14b A. gastrica dextra ventralis, 15 A. pancreaticodudenalis, 16 A. ileocecalis. 


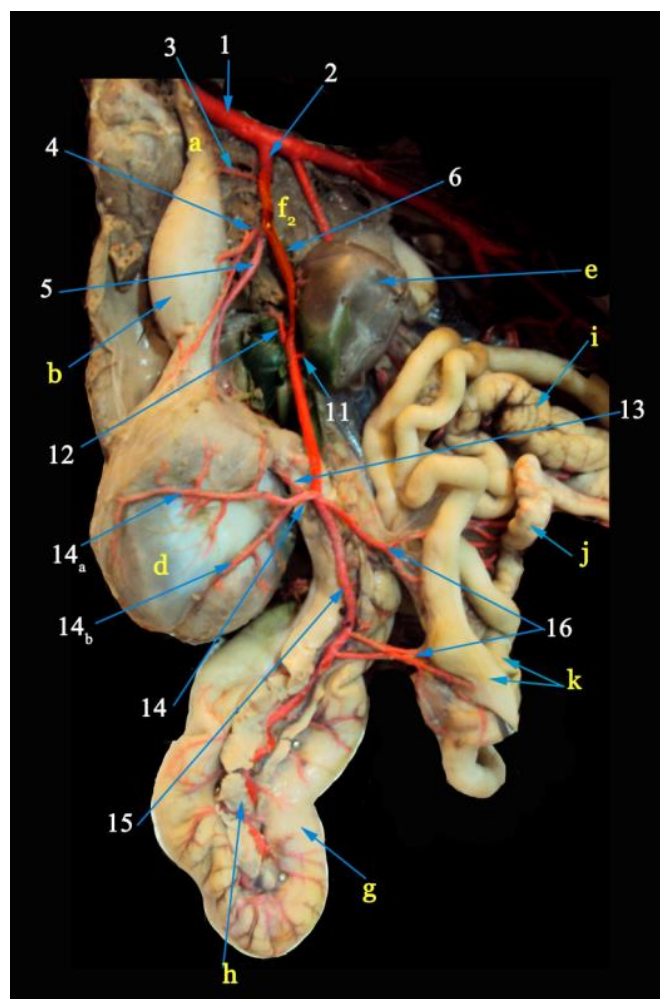

Fig (3): Photograph showing the branches of the right ramus of the celiac artery in chicken.

\section{Legend for figures (1-5)}

I-V: Costae (numerical),

a Oesophagus, b Proventriculus gastris, c Ismuth gastris, d Ventriculus gastris, e Splen, $f_{1}$ Lobus sinister hepatis, $f_{2}$ Lobus dexter hepatis, $g$ Duodenum, $h$ Pancreas, i Jejunum, j lleum, k Cecum,

1 Aorta descendens, 2 A. Celica, 3 A. esophagealis, 4 A. proventriculus dorsalis, 4a A. gastrica dorsalis, 4b Rr. Esophageales, 5 Ramus sinster arteriae celicae, 6 Ramus dexter arteriae celicae, 7 A. proventrcularis ventralis, 8 A. gastrica ventralis, 9 A. hepatica sinistra, 9 A. hepatica sinistra, 10 A. gastrica sinistra, 10a A. gastrica sinistra dorsalis, 10b A. gastrica sinistra ventralis, $11 \mathrm{Aa}$. Lienales, 12 A. hepatica dexter, 13 A. gastrodudenalis, 14 A. gastrica dexter, 14a A. gastrica dextra dorsalis,

$14 \mathrm{~b}$ A. gastrica dextra ventralis, $15 \mathrm{~A}$. pancreaticodudenalis, $16 \mathrm{~A}$. ileocecalis. 


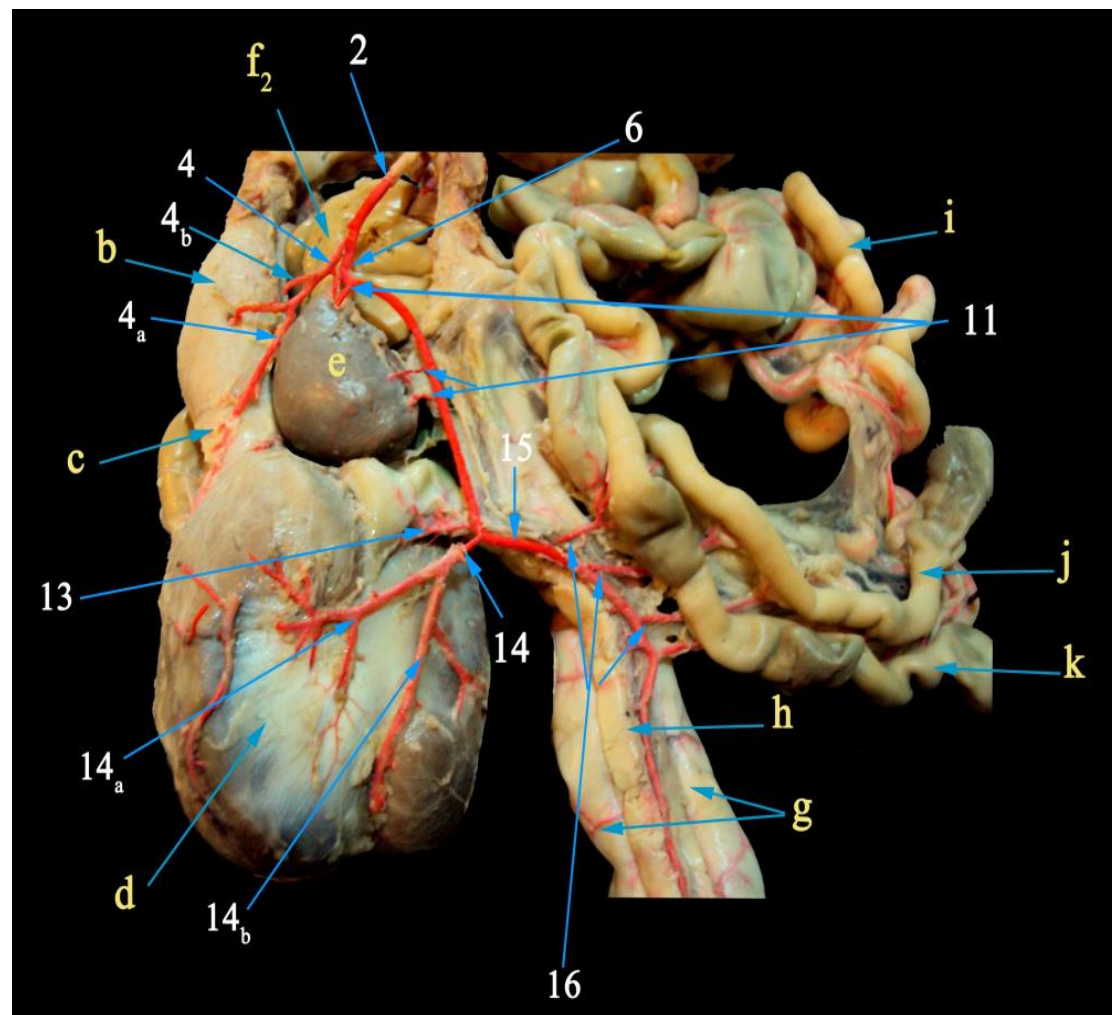

Fig (4): Photograph showing the branches of the right ramus of the celiac artery in chicken.

\section{Legend for figures (1-5)}

I-V: Costae (numerical),

a Oesophagus, b Proventriculus gastris, c Ismuth gastris, $d$ Ventriculus gastris, e Splen, $f_{1}$ Lobus sinister hepatis, $f_{2}$ Lobus dexter hepatis, $g$ Duodenum, $h$ Pancreas, i Jejunum, j lleum, $k$ Cecum,

1 Aorta descendens, 2 A. Celica, 3 A. esophagealis, 4 A. proventriculus dorsalis, 4a A. gastrica dorsalis, 4b Rr. Esophageales, 5 Ramus sinster arteriae celicae, 6 Ramus dexter arteriae celicae, 7 A. proventrcularis ventralis, $8 \mathrm{~A}$. gastrica ventralis, $9 \mathrm{~A}$. hepatica sinistra, $9 \mathrm{~A}$. hepatica sinistra, $10 \mathrm{~A}$. gastrica sinistra, 10a A. gastrica sinistra dorsalis, 10b A. gastrica sinistra ventralis, $11 \mathrm{Aa}$. Lienales, $12 \mathrm{~A}$. hepatica dexter, $13 \mathrm{~A}$. gastrodudenalis, $14 \mathrm{~A}$. gastrica dexter, 14a A. gastrica dextra dorsalis,

14b A. gastrica dextra ventralis, $15 \mathrm{~A}$. pancreaticodudenalis, $16 \mathrm{~A}$. ileocecalis. 


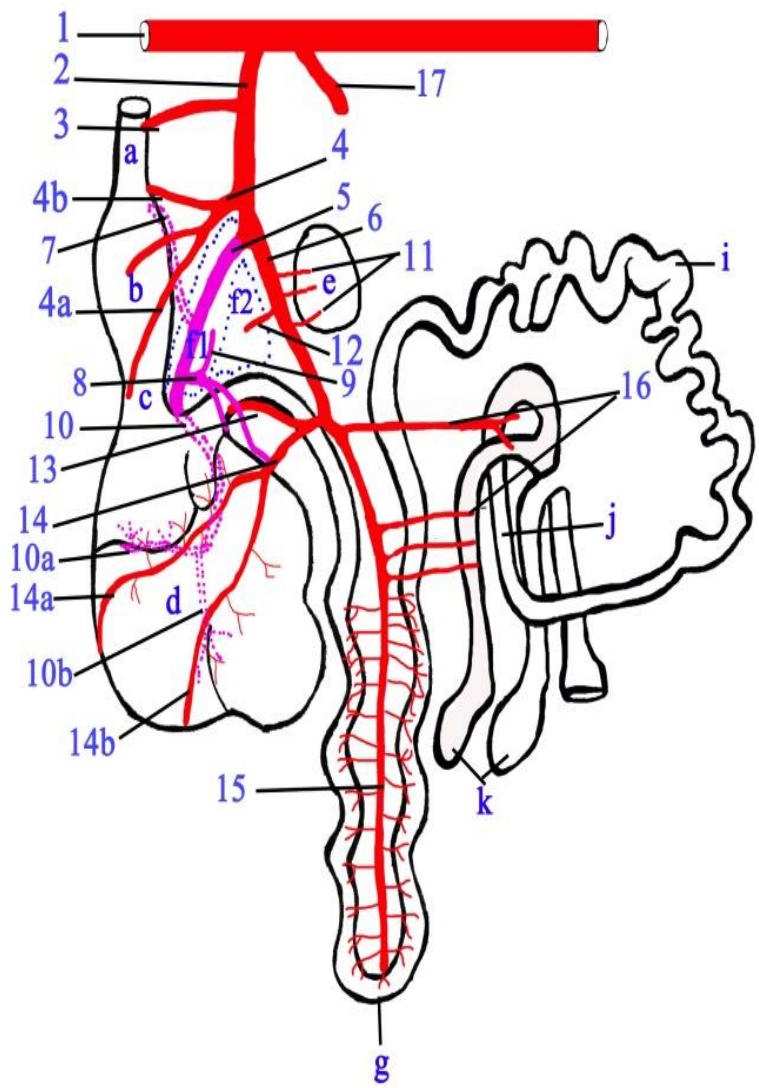

FIG (5): Diagram illustrates the branching pattern of the celiac artery in domestic fowl.

\section{Legend for figures (1-5)}

$\mathrm{I}-\mathrm{V}$ : Costae (numerical),

a Oesophagus, b Proventriculus gastris, c Ismuth gastris, d Ventriculus gastris, e Splen, $f_{1}$ Lobus sinister hepatis, $f_{2}$ Lobus dexter hepatis, $g$ Duodenum, $h$ Pancreas, i Jejunum, j lleum, k Cecum,

1 Aorta descendens, 2 A. Celica, 3 A. esophagealis, 4 A. proventriculus dorsalis, 4a A. gastrica dorsalis, 4b Rr. Esophageales, 5 Ramus sinster arteriae celicae, 6 Ramus dexter arteriae celicae, 7 A. proventrcularis ventralis, 8 A. gastrica ventralis, 9 A. hepatica sinistra, 9 A. hepatica sinistra, 10 A. gastrica sinistra, 10a A. gastrica sinistra dorsalis, 10b A. gastrica sinistra ventralis, $11 \mathrm{Aa}$. Lienales, $12 \mathrm{~A}$. hepatica dexter, $13 \mathrm{~A}$. gastrodudenalis, $14 \mathrm{~A}$. gastrica dexter, $14 a$ A. gastrica dextra dorsalis,

$14 \mathrm{~b}$ A. gastrica dextra ventralis, $15 \mathrm{~A}$. pancreaticodudenalis, $16 \mathrm{~A}$. ileocecalis. 